\title{
The Financial Impact of Joining the Chain and Improving Hotel Rating: A Case Study in Russia
}

\author{
Lina Krengel \\ Graduate School of Business, Stamford International University, Bangkok, Thailand \\ Email:linakrengel1209@gmail.com
}

How to cite this paper: Krengel, L. (2016) The Financial Impact of Joining the Chain and Improving Hotel Rating: A Case Study in Russia. Open Journal of Business and Management, 4, 659-674.

http://dx.doi.org/10.4236/ojbm.2016.44066

Received: July 13, 2016

Accepted: September 3, 2016

Published: September 7, 2016

Copyright $\odot 2016$ by author and Scientific Research Publishing Inc. This work is licensed under the Creative Commons Attribution International License (CC BY 4.0).

http://creativecommons.org/licenses/by/4.0/

\begin{abstract}
The objectives of this study were to consider the development of hotel chains in Russia and, further, to analyze the financial advantages or disadvantages of joining as part of the largest hotel chain's membership, as well as to analyze the financial activity of the company before and after joining the chain. The theoretical foundation of this research was based on overall theories of economic development. This research was conducted within a case study framework. The research instruments used were interviews of hotel employees for thematic analysis, and chronological analysis of the hotel's financial performance during two periods: 2010-11 and 2012-13. Findings of the research indicate that joining a well-known and large hotel chain as well as an improved hotel ranking has a significant financial impact on the hotel studied within this case study. It certainly improved the image of the hotel in the market, increased its reputation, and made it more recognizable.
\end{abstract}

\section{Keywords}

Analysis, Development, Hotel Chain, Financial Activity, Advantages

\section{Introduction}

The hospitality industry is a business that focuses on services related to the reception and guest service. This business consists of types of services that are based on the principles characterized by friendliness towards guests and providing a quality experience.

First mention of the hospitality industry, which provides services such as accommodation and food, can be found in manuscripts that scientists refer to the eras of ancient Greece and Rome. One of these documents is the Code of the Babylonian King Hammurabi (about $1700 \mathrm{BC}$ ).

In the twentieth century, the hospitality industry flourished. The United States and Europe were leaders in this field. New forms of organization of hotel facilities, such as 
uniting hotel chains in unions, were everywhere.

In today's hospitality industry, competition is constantly increasing. To be competitive in the market of hotel services, not only to maintain its market segment, but also to expand it, hotel managers need to be in constant search of new forms and methods of working with guests. The new philosophy of modern business is particularly evident in the hotels belonging to international hotel chains. In Russia, the number of hotels that belong to a particular chain is negligible. Most of the multinational companies have headquarters in the United States or Europe.

The past few decades were the era of revolutionary changes for the hotel business. The post-industrial society, which, according to economists, has formed nowadays, is characterized by the growth of demand for all kinds of services, including hotels. Almost all organizations provide services. However, in relation to the hospitality industry, service is the basis of economic activity. In Russia, the service sector is overtaking manufacturing sector in terms of growth and the emergence of new types of services, in its adaptation to the needs of the market and consumers. This is due to lower initial cost compared to the production sphere. For hotels, this is not quite true, but the relatively high initial costs pay off very quickly if there is a good market entry strategy.

Globalization is another important trend of recent decades in the field of market development of the hospitality industry. The need to have their businesses in key global markets has led to many mergers and acquisitions taking place since the late 1980's and until the present time.

In recent years, Russia has experienced a rapid development of the hotel industry. However, quantitative growth is not always accompanied by a simultaneous increase in the quality and level of service. Because of that, up-to-date domestic hotels are inferior in service level to their foreign competitors-the international hotel chains of the East and West. Moreover, this difference is a serious problem in the Russian guest service, which only gets worse in the cities away from the main tourist centers. According to the Ministry of Economic Development, nowadays there are about 4000 hotels in Russia. More than $70 \%$ of them are not fitting any of the existing categories. In some cities of the Russian Federation, the hotels do not meet all the necessary sets of requirements.

Leaders in the development of the hotel industry in Russia today are Moscow, St. Petersburg and Sochi. The hotel business in Kaliningrad, Tomsk and Volgograd regions, the Urals, and Krasnoyarsk, is rapidly growing.

The system of hotel management corporations contributes to the creation of a number of advantages, which allow for a greater degree of tourism enterprises to improve the quality of the tourist product, diversify the services offered within the market segment, and increase individualization of customer service.

Today, there are more than 300 hotel chains, from small to the "heavyweights", that include thousands of hotels.

The hotel that the researcher considers in this study is related to the so-called voluntary chain. This association is not a usual form; because it lets, their representatives manage hotels independently. However, they provide support and open new horizons for hotels and their owners. 
The researcher exams how becoming part of the chain affected the hotel's financial performance. Moreover, the researcher analyzes if there is a significant differences in the hotel's financial results.

This study focuses on the activity of an international hotel chain representative in Russia. The aim of the study is to examine the previous and current state of the hotel, and analyze advantages and disadvantages of joining the franchise.

\section{Theoretical Framework}

\subsection{Globalization}

Currently, tourism becomes increasingly global. Becoming a global tourist market is accompanied by a powerful process of trans-nationalization, which finds expression in the international interweaving of private capital, strengthening the ties between the monopolies of different countries, and a wide development of transnational companies in the tourist business.

Studies show that, the process of globalization includes several factors that affect tourism. The ability to reach foreign markets, the development of transport system, and evolution of technology all have a big impact on tourism industry. The increasing number of tourists, business travelers, etc. causes changes in hotel industry and an increasing number of accommodation facilities. To run a successful business and to increase their power in the market, hotel companies need to expand. Nowadays, hotel chains are the most forceful form of hotel business organization. The most substantial factor of economic activity in this industry is proper management [1].

This new economic education leads to a higher level of concentration and centralization of production and capital, as well as promotes the adoption and dissemination of international standards of tourist service. A prime example of such economic entities in the tourism sector is a global hotel chain.

Nowadays, the hotel industry is characterized by the increasing consolidation of the leading international hotel chains. Companies want to create portfolios of brand hotel chains to meet the needs of different categories of consumers. Thus, the company "Hilton" includes nine known hotel brands: "Hilton", "Conrad Hotels \& Resorts", "Doubletree", "Embassy Suites Hotels", "Hampton Inn”, "Hampton Inn \& Suites", "Hilton Garden Inn", "Hilton Grand Vacations", "Homewood Suites by Hilton", and "The Waldorf Astoria Collection". A French company "Accor" owns brands from economy to luxury class: "Formule 1", "Ibis", "Novotel”, "Mercure", "Pullman" and "Sofitel” [2].

\subsection{History of Hotel Chains}

A hotel chain is an association of hotel companies that have the same level of service, the same set of services, similar design and approach to work with their guests and working under the direct control of the chain management [3].

Usually, one hotel can give an impression of the others included in the same chain. Thus, the hotels from the chain have the same submission, same system of standards and services. Hotel chains may cover one or more countries, which means they can be 
national or international.

There are currently more than 300 hotel chains, with the total number of rooms nearing 2,000,000.

A special role in the development of hotel chains belongs to the United States, since it was there where they gained popularity and begun to spread throughout the world. In 1794 in the United States the first hotel was opened-the 70-room "City Hotel" on Broadway in New York. In 1829, a hotel was opened in Boston. "Tremont" was the first in the United States first class hotel-a corridor, reception, locks on the doors of rooms (single and double) and even free soap for guests. This event marked the beginning of a boom in the hospitality of this country [4].

By the early $20^{\text {th }}$ century, Russia began to open excellent hotels, built according to international projects and meeting all the requirements of that time. The process of development of the hospitality industry in Russia has been adjusted during the Soviet period, when the development of the hotel industry followed the five-year growth plans under the state planning and therefore was isolated from world trends. As a result, by the 1990's the Russian hospitality industry was far behind the international standards, and many people associated its revival with the arrival of international brands to the country [5].

In the mid-90, several brands such as Marriott, Holiday Inn, Sheraton, and Kempinski penetrated Russian market. However, foreigners have faced some problems in Russia: a rare hotel was able to meet their strong standards that were built up in decades.

The Famous International Hotel Company has successfully begun to apply waste scheme. They are quite aware that the ability to build their own chain gives them an undeniable advantage [4].

"Radisson Hotel and Resorts Worldwide", in addition to the hotel's construction in Moscow in 1991, opened a hotel complex in Sochi two years later. Somewhat later, they added one more four-star hotel there- "Lazurnaya Hotel Pia" that was aimed at skiers. However, the interests of the corporation are much wider: "Radisson Hotel and Resorts Worldwide" is trying to cover tourist and business centers of the former USSR by the chain of hotels [6].

The American company "Best Western" represented the second largest chain in Russia and other former Soviet states. "Best Western" also extend their interests to the North-West of Russia and the Baltic States. "Best Western" rapidly fills the niche of inexpensive four-star hotels. It drew attention to the idea of a niche hotel, organized not only for travelers, but also for business people. By implementing a tourist-class hotel on the market of the Baltic States, the company began the development of this segment in Russia [7].

In general, world's major hotel chains entered Russia in the $90^{\text {s }}$, but their expansion has not followed suit because of the serious social and economic problems that occurred in our country in this period [8].

\subsection{Types of Hotel Chains}

The research shows that, to get the best position in the international market, there is the 
process of expansion of international hotel chains and establishment of new companies, including well-known hotels. The goal of developing new hotel companies is to provide financial resources for management, in order to improve their business standards [9].

There are three types of hotel chains: corporate chains, management companies, and voluntary chain associations.

The first type, corporate chains are well known by their brand or trademark. The biggest corporate chains established many brands-trademarks, which may best show the quality of service provided.

Franchising and management contracts, as well as different standards of sales, including companies from other economic branches and means, are used, because business activities are done in different ways on the national and international levels [9].

The management company is an independent legal entity, associated with its managed objects by contract, and providing overall guidance and monitoring of common standards' compliance [10].

Currently, there is such type of contract as a franchising. In this case, a large company (franchisor) transfers its rights to use the brand, marketing and booking systems, as well as Operations Management System, to franchisees. They (franchisees) report to the franchisor, maintain its standards of service and comfort, pay the fee of an agreed amount of $3 \%$ - $4 \%$ of turnover, while also making a down payment of around $30 \%$ [11].

The franchisor leases its service standards, and with them their reputation as well as its technology, within this contract. The franchisor helps the franchisee to organize activities to promote the hotel product, to purchase equipment, and to train its staff.

The advantage of a hotel company that provides franchise is the fact that it provides a significant amount of selling points in various countries without big investments. The company distributes in the market with minimal financial risk. Leading corporate chains are the largest donors [9].

The best examples are corporate chains such as InterContinental Hotels Group (86\% are franchised), Wyndham Hotel Group (out of 7.043 hotels, 7.016 are franchised), Choice Hotels International (all the hotels are franchised), etc.

Third type is voluntary chain (association). The researcher will focus on this type deeply. This type of chain bases its activities on providing global marketing services and hotel reservations for independent hotels and corporate networks [11].

The origin of voluntary chains is associated with internationalization and globalization of hospitality, especially the hotel business. Hotel companies join voluntary chains when they are not able to follow the expansion of activities. The activities of voluntary chains are associated with sales and reservations, advertising, promotional activities, cooperation with airlines, other services, etc. [12].

The largest hotel voluntary chain in the world is the American chain "Best Western International", numbering over 4000 hotels and 270,000 rooms [13].

\subsection{One of the Biggest International Hotel Chain in Russia}

The biggest hotel chain in the world includes around 4000 hotel in more than 84 coun- 
tries by 2010. The company is a union of independent hotels with their own charm and high service standards. Management of the chain lets chain's hotels retain independence in regards to the guest service, staff training, sales and marketing. On the other hand, it provides its members with consultancy services, support, and its reservation system.

In 2006 , the company celebrated their anniversary -60 years.

The company provided an informational network for its hotels, where each of them would support the others.

In 1976, the world chain included hotels of Mexico, Australia and New Zealand.

In 1979, over 15 million guests visited the chain's hotels. The sales revenue reached 1 billion dollars.

In 1981, it was known as the biggest chain of independent hotels.

Nowadays, the company has 30 offices in four world regions. 2100 of 4000 hotels are located in the United States of America, 244 in Europe, 309 hotels in Australia and New Zealand, 85 in South and Central America, 63 hotels in Asia and the East, 7 hotels in Africa.

In July 2011, the brand came to Russia. This brand has decided to engage one of the Moscow hotels [14].

In this study, we would like to focus on the Moscow hotel, which is a part of the largest hotel complex in Europe.

As per the information on the official website, the hotel offers 990 rooms of different categories, from Standard to President Suite. Each room has a mini-fridge and air conditioning. There is also an ironing room and a water cooler on every floor.

All rooms are equipped with electronic locks, mini-safes, and fire alarm system.

The hotel is ready to provide more than $2000 \mathrm{~m}^{2}$ for banquets and conferences. Its restaurant complex includes four restaurants, 3 banquet halls and two bars.

According to the interview of the hotel's Director General to the RATA News, the need for rebranding was due to the current market situation, in which the number of hotels in the city was growing, so the flow of visitors in recent years has reduced, whereby it became necessary to look for new opportunities for growth. The hotel needed a recognizable brand, thus they went to one of the famous hotel chains. They assumed that joining this chain would give an additional 15\% of occupancy.

The process of preparing the hotel to join the international network took four months. The monitoring showed high standards of hotel service quality, the number of rooms and technical parameters that met the standards of the chosen chain. As a result of visiting the "mystery guest's" visit, the hotel has received a 93.3\% rating of accordance to international standards. Under the agreement, the hotel receives a brand, technology, international standards of the chain, and the network, in turn, includes the hotel in their international hotel reservation system [14].

In the year 2012, the hotel was certified as a four-star hotel. According to the website this promotion meant that the "hotel is thoughtfully designed to meet the needs of both business and leisure travelers who are looking for enhanced style and comfort". 
According to the company corporate website, the four-star type assures guests that the hotel provides the following services and hotel amenities, as well as guest room amenities, among others:

- Gym.

- Restaurants.

- Spa and massage service.

- Multilingual staff (English, German, Spanish, Russian).

- Shoe shine.

- Barber/beauty shop.

- Airline desk.

- Business center, 24 hours.

- Free Wi-Fi Internet in all rooms and public areas.

Guest Room Amenities:

- Coffee/teamaker.

- Refrigerator.

- Iron, ironing board.

- Mini-bar.

- Bathrobe.

- Bath room phone, available in apartment.

- Turn down service.

\subsection{General Advantages of Hotel Chains}

There are several advantages of joining a hotel chain:

- Ability to purchase large quantities of goods and services at wholesale (discounted) prices;

- Human resources. Hotel chain provides centralized training for specialists, which significantly reduces the costs of each member of the chain individually. In addition, participation in the chain allows its members to use the services of highly paid specialists-experts in their fields;

- Promotions and advertising. The advertising campaign at the national level-in newspapers, magazines, radio and television - is a big part of the budgets of independent hotels. However, the hotel chains allow their members to allocate the cost of advertising and promotion among themselves, so everyone can enjoy the benefits of advertising campaigns;

- Centralized booking system. It allows individual members to combine their business chain. A large number of reservations, which under other circumstances might go to competitors, are made among hotels in the chain;

- Financing. Chains have an easier time raising their capital and returning it to expand or improve the efficiency of their work;

- The centralized system of accounting, market research, construction and real estate operations. People employed in these areas can serve all the hotels included in the chain [10]. 
The purpose of a hotel chain was to increase the efficiency of the hotel due to the benefits derived from the strategic cooperation [15].

Unlike other companies involved in hotel business, hotel chains have defined standards in all business areas, their own philosophy and marketing strategy, a unique booking system, human resource education etc. All these factors make them not only recognizable on the market but also the main carriers of tourism development in the future [16].

\subsection{Disadvantages of Hotel Chains}

Despite the great advantages of joining a hotel chain, this process is not so perfect, and has a number of disadvantages:

- Standardization leads to monotony, which is not acceptable by travelers looking for novelty and diversity;

- The absence of national and authentic touch repel some guest who want something new;

- The process of introducing new technologies and management methods takes a long time because of the complexity of the administrative personnel;

- Hotels chains suppress competitors, which leads to slower progress in this industry. Small and independent hotels sometimes do not withstand competition in the fight for the customer and are forced to leave the market;

- Lack of individual approach and atmosphere of home comfort. Many customers remain unsatisfied by standardized, "impersonal" service and prefer to stay in independent hotels;

- Poor service in one of the hotel affects the image of the entire brand;

- The necessity of extra expenses on membership fees.

\section{Methodology}

The study is written within a case study framework. A case study is a detailed study of a specific situation rather than a sweeping statistical survey. This method is used to specify a broad topic [17].

From the study of the financial impact of joining the chain, the researcher analyzed financial activity of the hotel by conducting financial statements and official requirements. Therefore, the methodology includes conducting formatted raw data, population and sample size, conceptual framework, research planning process, hypotheses of the study and research design and instrument.

Qualitative research is designed to capture and analyze difference in performance of the company before and after joining the one of the largest hotel chain in the world. The purpose and process of qualitative research may appear unfocused due to sample size, which is too small and does not seem to represent the actual situation on the hospitality market. Therefore, it is complicated to know whether the results are accurate as the data may be solid. The opinions of the research may be biased with their findings [18]. 
Different methods of data collection and analysis, such as observation and interview, as well as analyzing of the primary data were used. Case studies usually have a very narrow focus, which results in detailed descriptive data, which is unique.

The researcher collected data from hotel heads of the department and from the General Manager (eight in total). 3 out of 8 respondents are women. 2 of them are below 35 years old. The age range of male respondents' varies. 2 out of 5 respondents are younger than 30 years old. The age of 2 other interviewees is below 45 years old. The General Manager is 51 years old.

The researcher conducted the interview via Skype due to the living in a different country. Each interview lasted at least 30 minutes because of the respondents' workload.

The researcher formerly worked in this hotel and was aware of the situation regarding the joining of the chain and the possible consequences. Therefore, this enabled the researcher to understand the reasons for joining as well as the potential advantages and disadvantages of joining the chain. The observation of hotel's performance was done during the time the researched had been studying in Moscow and had been working in the hotel. The researcher observed guests portrait that changed after joining the chain, changes in decoration, and in working process style.

Moreover, the researcher was able to obtain access and analyze financial reports, which indicated the hotel's financial performance: sales revenue per month and per year, and occupancy per day, month and year.

Sales revenue-is an amount realized from selling services (in considered case) in a specific period of company's operation. Using the sale revenue reports, the researcher was able to see and analyze the dynamics of revenue growth during the four years under examination. The report shows occupancy revenue as well as other income items on a monthly basis using average, minimum and maximum values.

Occupancy is the number of hotel rooms that have been sold, compared to the total number of hotel rooms in the hotel. It is always shown as a percentage of the total rooms of the establishment.

Using an occupancy report for a year, the researcher was able to analyze the effect of entering into the hotel chain, as well as how the improved hotel rating affected the hotel's overall occupancy rates. The report is a table that shows the occupancy for each room category, average occupancy for the month and the year, and the total load for the month and for the year.

In this study, the general factors that affect a hotel's financial indexes are joining the chain, category increase, political situation, economic situation in the country. Before adopting the franchise, it was a three-star hotel, surrounded by four similar hotels. However, after joining the chain, the hotel acquired a world known brand that helped it to get leading positions in the area and increase its financial results. Moreover, the considered hotel received a 4 -star status according to the Russian standards.

Together with the world known brand, the hotel received great support from the chain. However, the hotel owner and operator are fully independent in making any de- 
cisions regarding the operation of the hotel.

Nowadays, Russia has a system of Russian hotels' classifications, approved by the Russian Federation Government on July 15, 2005. The new system corresponds to Western standards and does not contradict the conditions of the State classification system, approved by the order of Ministry of Economic Development on June 21, 2003.

Before membership in the chain, the hotel studied (which is presented anonymously) had only three stars and had an appropriate set of services and price policy.

Political situation is a specific balance of political forces, a set of events, and a result of political activity [19]. However, not every event may affect travel and hotel business. In this study the researcher is considering only situations that have affected hospitality industry. During the period 2010-2013 the political situation in Russia and especially in Moscow was stable. The number of international and local tourist varied according to the season, but neither sharp rise nor fall were fixed.

The researcher is considering a lack of any political events as an ideal environment to run the business.

Economic crisis that erupted in the international financial market in summer of 2008, has affected the economies of most countries of the world [20].

Hospitality felt the impact of the crisis, even in the summer season. Hoteliers stated that the profitability of their companies has fallen by a third.

The economic crisis has significantly weakened and reduced the attractiveness of the hospitality industry in Russia. Following the decline of profitability project funding has decreased, pace of commissioning of new hotels has declined, and payback period and investment risks have increased. In general, Russian hotel industry was much weaker in the next few years [21].

The period from 2011 to 2013 may be considered for the hotel industry as reconstructive.

Financial activity is an economic category, reflecting the state capital in the process of circulation, and the ability to self-develop as a business entity at the fixed time [22].

The financial activities of the company cover the processes of formation, movement and preservation of assets of the enterprise, control over its use.

Financial activity is characterized by the provision of financial resources, which are necessary for normal functioning of the enterprise, appropriate placement and using of these resources, financial relations with other legal entities and individuals, solvency and financial stability [23].

Another key factor to estimate the hotel performance is occupancy. Unless it is not the result of commercial activity, it may show a clear picture of the situation, and indicate the efficiency of commercial activity.

\section{Data Analysis}

When the researcher met the interviewee, the interviewer proceeded to greet the interviewee and explain the purpose of interview. Since the researcher knew all of the interviewees personally, it was not difficult to discuss the topic and ask extra questions if 
needed. The interviewees were supportive of the aim of the research and supplied information freely as needed. The process was conducted in approximately 45 minutes.

As indicated in Table 1 the biggest part of income hotel received from selling rooms, 99.64\%. Extra services and facilities in 2010 were not popular because of the guest segment. Other services make up together only $0.36 \%$ of income. The biggest part of them falls in the conference rooms and business center. It means, that guest spent minimum time in the hotel (1 night) and did not use extra services. The small share of parking indicates that the majority of guests came by taxi or public transport, or decided to leave their car in the free parking area. This data is supported by the words of interviewees that are provided above.

Comparing the year 2010 and year 2011 when the Hotel joined the chain, in Table 2 we can see the rapid increase in income in every department. New guests, as was mentioned by respondents, used extra service such us restaurants, bars, MICE facilities more often, thus, the share of room income decreased. However, the overall income increased up to $49 \%$. Moreover, as we can see in this table, the hotel separated banquets as an independent source of income. The biggest increase in share we can see in food \&

Table 1. Financial performance, year 2010.

\begin{tabular}{ccc}
\hline Indicators & Income per year in 2010, ths. rub. & Share (\%) \\
\hline Rooms & $609,913,476.6$ & 99.64 \\
Meals & $653,490.3$ & 0.11 \\
Beverages & $105,871.6$ & 0.02 \\
Telephone calls & $63,320.2$ & 0.01 \\
Parking & $106,666.6$ & 0.02 \\
Office rent and misc. & $148,614.1$ & 0.02 \\
Conference rooms \& business center & $1,115,423.1$ & 0.18 \\
Total & $612,106,862.5$ & 100
\end{tabular}

Table 2. Financial performance, year 2011.

\begin{tabular}{ccc}
\hline Indicators & Income per year in 2011, ths. rub. & Share (\%) \\
\hline Rooms & $720,262,607.93$ & 78.58 \\
Meals & $114,786,018.89$ & 12.52 \\
Beverages & $22,725,663.94$ & 2.48 \\
Telephone calls & $1,659,920.48$ & 0.18 \\
Parking & $2,759,766.53$ & 0.3 \\
Office rent and misc. & $2,199,500.45$ & 0.24 \\
Banquets & $28,440,304.65$ & 3.1 \\
Conference rooms \& business center & $23,832,178.80$ & 2.6 \\
Total & $916,665,961.3$ & 100 \\
\hline
\end{tabular}


beverage department $-12.42 \%$. The share of parking also has increased up to $0.28 \%$. This increase is caused inter alia by the gain of conference share $(2.42 \%$.) The new guest segment, such us Western business tourist used hotel not only as a place for a sleepover, but also as a place for meetings and even conferences, as one of the respondents suggested:

“...But after joining the chain we received new guests who are well fixed and they can spend more money not only on accommodation but on other extra services as well”.

In the year 2012, the growth of income continued to increase. Compared to the year 2010 - up to $60 \%$, to the year 2011 - up to $7 \%$, as indicated in Table 3, the share of rooms captured a leading position again and increased up to $3.21 \%$. This caused a slight decrease in other shares; however, it did not affect the overall income. It might be caused by new room categories that were open in the Hotel and improving its ranking. The data is complied and supported by respondents' words:

“...joining the chain, of course, affected the financial performance of the hotel.

Despite the economicl political situation, we were able to stabilize the financial per-

formance of the hotel. Being independent hotel, in my opinion, we could not have achieved such financial indicators".

The year 2013 showed the effect of joining the chain very clear. The income increased up to $65 \%$ comparing to the year 2010, up to $10 \%$ comparing to the year 2011 and up to $1 \%$ comparing to the year 2012. The words of all respondents are supported by this data. The financial indicators in Table 4 show the significant growth after joining the chain.

Occupancy is the main indicator of hotel operations as the enterprise. It calculates hotels value on a specific date, as well as its average value for the month, quarter, and year, in order to determine how effectively rooms are sold, or how hotel operation is economically viable.

The average occupancy rate of hotels in the world is relatively stable for several years and is $66 \%-68 \%$ and the occupancy of hotels in Moscow is an average of $73 \%$.

Table 3. Financial performance, year 2012.

\begin{tabular}{ccc}
\hline Indicators & Income per year in 2012, ths. rub. & Share (\%) \\
\hline Rooms & $804,651,049.7$ & 81.79 \\
Meals & $99,359,508.7$ & 10.1 \\
Beverages & $20,560,624.2$ & 2.09 \\
Telephone calls & $1,574,012.1$ & 0.16 \\
Parking & $2,951,573.7$ & 0.3 \\
Office rent and misc. & $2,065,891.6$ & 0.21 \\
Banquets & $30,008,816.2$ & 3.05 \\
Conference rooms \& business center & $22,586,431.8$ & 2.3 \\
Total & $\mathbf{9 8 3 , 7 5 7 , 9 0 8}$ & 100 \\
\hline
\end{tabular}


This indicator:

- Provides a clearer picture of how the hotel uses the room.

- Reflect how the company relative to its maximum capability of producing revenue (the total of all prices for each room in the hotel).

- Keeps track of developments in the management capacity.

Figure 1 shows what year was the most successful for the hotel in terms of occupancy. Comparing year 2010 with the first year in the chain we may see the growth for $2.22 \%$. 2012 was less successful, however, as we remember from the Table 4, despite the decrease in occupancy for 5.08\% (comparing with 2011), the hotel had the revenue increase up to $10 \%$. This was caused by the establishment of new room categories and updated price policy. The Hotel attracted new solvent guests; however, they lost their frequent guest who did not accept changes.

\section{Discussion}

The purpose of a hotel chain is to increase the efficiency of the hotel [15].

Table 4. Financial performance, year 2013.

\begin{tabular}{ccc}
\hline Indicators & Income per year in 2013, ths. rub. & Share (\%) \\
\hline Rooms & $859,059,589.6$ & 84.82 \\
Meals & $84,040,482.5$ & 8.3 \\
Beverages & $15,191,783.2$ & 1.5 \\
Telephone calls & $1,414,998.6$ & 0.14 \\
Parking & $2,734,797.3$ & 0.27 \\
Office rent and misc. & $1,924,284.1$ & 0.19 \\
Banquets & $23,091,540.2$ & 2.28 \\
Conference rooms \& business center & $25,319,422.4$ & 2.5 \\
Total & $1,012,776,897.9$ & 100
\end{tabular}

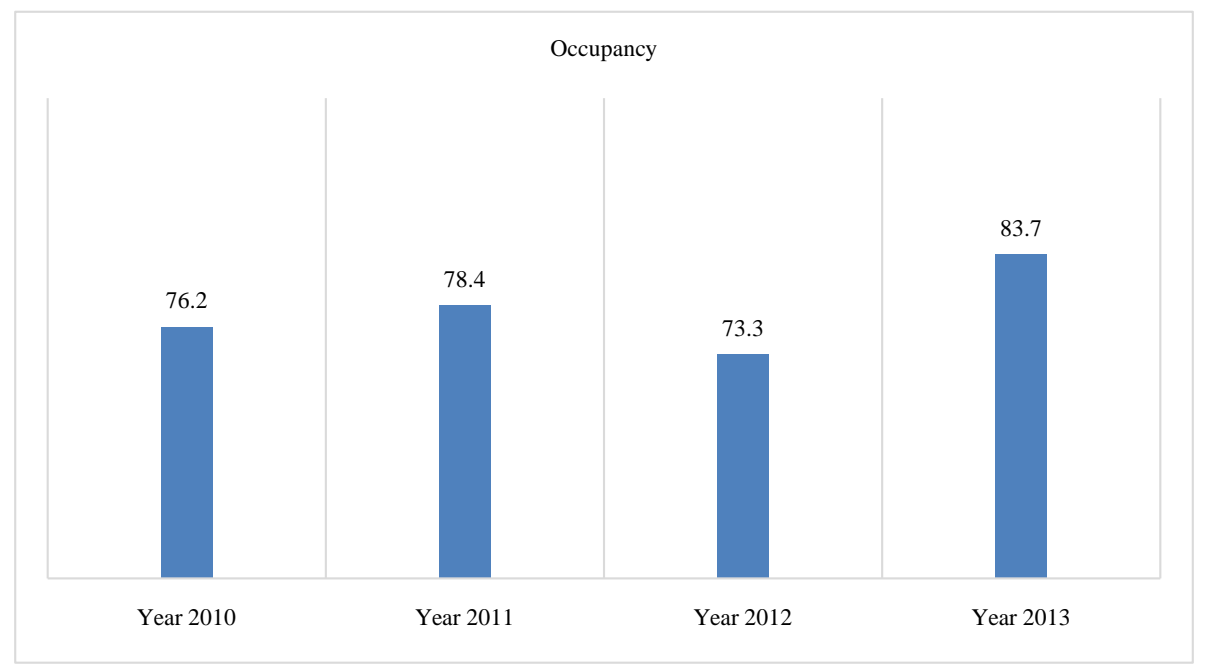

Figure 1. Occupancy. 
Joining a chain provides a significant amount of selling points in various countries without big investments. The company distributes in the market with minimal financial risk [9].

Unlike other hotel chains, which are often compound hotels owned by the company and the franchise, every hotel in the chain is both a part of the franchise and "independent" hotel. The chain does not offer franchises in the traditional sense (where the person who received from franchisees and the company that provides the franchise to sell their products at a discount operate on a commercial basis). Considered hotel chain operates as a non-profit membership association.

Firstly, it helps in online sales: corporate website provides a reliable channel online booking in multiple languages; the channel generates around $\$ 1.3$ billion in revenue in the network of hotels around the world.

Connecting to all global reservation systems (GDS systems: Amadeus, Sabre, Galileo and Worldspan). Interviewees 1, 2 and 3, mentioned this point. The hotel received his first bookings through this channel immediately after signing the contract. The company offers a centralized service for the management of reservation channels, aimed at increasing the number of rooms each loading hotel chain and, as a result, the profit growth of hotels.

Participation in the loyalty programs for "Frequent Guest" (Frequent traveler program), uniting 11 million customers. This point is not less important. Cardholders are so called new type of the guest, Western business travelers. This type of guests is more solvent, they are using more hotel's extra facilities and they are frequent, which means, they will return to the hotel every time they visit Moscow. Interviewees 3, 4 and 5, supported this point. Gaining additional $15 \%$ of market let the hotel improve its financial performance and strengthen market positions.

Online hotels loyalty program allows all hotels under the brand to earn $\$ 1.46$ billion per year.

The considered chain provides a variety of opportunities for advancement and growth in hotel sales with an access to key global corporate clients. The company presents its hotels at major international exhibitions such as MITT in Moscow, the ITB in Berlin and ABAV in Rio de Janeiro.

The considered chain also helps owners to control the quality of service at the hotel, check the degree of guest satisfaction by using its online tool offers Medallia leave your comments, which are delivered to the desktop of the hotel owner, providing invaluable analysis of the efficiency of the hotel.

The hotel used its own resources, such as employees, building, facilities, partners to build new product, to increase sales and occupancy, and to expand its influence in the market.

The development of hotel business is carried out not in isolation, but under the influence of a number of factors, the influence of which is independent of the market players. Hotel business as an economic sector can successfully operate in the presence of a favourable marketing environment. Therefore, prerequisites intensive operation of 
hotel businesses are monitoring the marketing environment, as well as planning and implementation of preventive measures aimed at reducing the negative impact of the marketing environment factors.

The political factor is not the only one that affects the financial performance of the hotel. The economic situation is also crucial.

Economic factors determine the trend and dynamics of development of hotel and restaurant business. The main economic factors that determine the formation of these industries is the rate of economic growth of the country, consumers income and their ability to pay, the state of the monetary sphere. In developed countries, the growth of social wealth is accompanied by an increase in the cost of the service sector in the total consumer spending.

The hotel market is now one of the fastest growing segments of the market.

Competition in the market is increasing every year. However, Russia still lags far behind the main indicators of tourism development of the world's leading countries, despite the fact that tourism is recognized as a priority area of the Russian economy.

The study was written in a case study framework. Limitations are caused by the framework and defined as an activity of the representative of the one of the largest hotel chain in Moscow, Russia.

This research is a qualitative research based on thematic qualitative analysis, which could be bias or incomplete. This research is quite comprehensive but it may lack certain analysis. Therefore, the researcher suggests that more research should be done in finding information regarding the financial impact of joining the hotel chain.

Unfortunately, researches in this area are scattered, fragmented and far from the development is a complex methodological support of the formation of the competitive strategies of joining hotel chains in Russia in the current and future conditions.

Summarizing all mentioned above, it should be recognized that the subject of the research is, of course, relevant and has both theoretical and substantial practical significance. The thesis is essentially one of the attempts to study the scope of the system of the international hotel chains in Russia and the development of comprehensive organizational and methodological recommendations of an effective management system. The solution to this problem will ensure the development of advanced forms and methods of effective management of the hospitality industry in Russia, which objectively corresponds to its strategic objectives of socio-economic development. The researcher also suggests observing the hotels joined the chain in different cities and countries during any politically instable events and economic events to create mote clear picture.

\section{References}

[1] Malyushenkova, E. (2014) Managing the Process of Hotel Chains Formation and Development on the Tourist Services Market. Electronic Journal of Economics and Environmental Management. http://economics.open-mechanics.com/articles/998.pdf

[2] Efremova, M. (2002) The Basic Technology of Tourist Business. Moscow: Os.

[3] Konovalova, D. (2003) The Rank of International Tourism In Modern International Economic Relationship. ROSSPEN. 
[4] Walker, J. (2008) Introduction to Hospitality. Moscow.

[5] Vavilova, E. (2005) Basics of International Tourism. Gardariki, Moscow.

[6] Aleksandrova, A. (2008) The Geography of International Tourism. Knorus, Moscow.

[7] Volkov, Y. (2008) Hotel and Tourist Business. Phenix, Moscow.

[8] History of Hotel Business Development. http://turgostinica.ru/gostinichniy-biznes-i-ego-razvitie-v-sovremennich-us/1-2-istoriya-ra zvitiya-gostinichnogo-biznesa/vse-stranitsi.html

[9] Susic, V. (2006) The Development and Territorial Allocation of Hotel Chains in the World. Scientific Journal Facta Universitatis, 6. http://facta.junis.ni.ac.rs/eao/eao2 00903/eao200903-11.pdf

[10] Karar, A. (2012) International Hotel Chains Development. International Law and International Relationship. http://evolutio.info/content/view/1954/232/

[11] Efimova, P. (2004) Economy of Hotels and Restaurants. New Edition, Moscow.

[12] Zhukov, A. (2007) Innovative Aspects of Management in Tourist Organizations. 2nd Edition. D.A.R.K, Moscow.

[13] Dzhandzhugazova, E. (2005) Marketing in Hospitality Industry. Academy, Moscow.

[14] Best Western Hotel Brand Is Coming to Russia (2011). http://www.cre.ru/rus/archivnews/12/0/17890/

[15] Katkalo, V. and Shemrakova, V. (2008) Network Strategies of Hotel Business. High Management School, Saint Petersburg.

[16] Volkov, Y. (2008) Hotel and Tourist Business. Moscow: Phenix.

[17] Shuttleworth, M. (2008) Case Study Research Design. https://explorable.com/case-study-research-design

[18] Patton, M. and Cocharn, M. (2002) A Guide to Using Qualitative Research Methodology. Médecins Sans Frontières, Paris.

https://evaluation.msf.org/sites/evaluation/files/a guide to using qualitative research met hodology.pdf

[19] Vasilik, M. and Vershinin, M. (2001) Political Ccience. Gardariki, Moscow.

[20] Maksimova, L (2010) Anti-Crisis Strategies of Tourism Development, Moscow. http://cyberleninka.ru/article/n/antikrizisnye-strategii-razvitiya-turizma

[21] Chizhkova, O. (2010) Hoteliers Are Thinking About Measures to Support Industries. http://prohotel.ru/article-142030/0/

[22] Tupicin, A. (2006) Management of Financial Stability of the Enterprise. Novosibirsk.

[23] Boronenko, S., Maslova, L. and Krylov, S. (2006) Financial Analysis of Entities. Ural State University, Yekaterinburg. 
Submit or recommend next manuscript to SCIRP and we will provide best service for you:

Accepting pre-submission inquiries through Email, Facebook, LinkedIn, Twitter, etc. A wide selection of journals (inclusive of 9 subjects, more than 200 journals)

Providing 24-hour high-quality service

User-friendly online submission system

Fair and swift peer-review system

Efficient typesetting and proofreading procedure

Display of the result of downloads and visits, as well as the number of cited articles

Maximum dissemination of your research work

Submit your manuscript at: http://papersubmission.scirp.org/ 